\title{
Sap flow in response to rainfall pulses for two shrub species in the semiarid Chinese Loess Plateau
}

\author{
Shengqi Jian*, Zening Wu, Caihong Hu, Xueli Zhang \\ College of Water Conservancy \& Environmental, Zhengzhou University, Science road 100, Zhengzhou, China. \\ *Corresponding author. Tel.: +86 18603814081. E-mail: jiansq@zzu.edu.cn
}

\begin{abstract}
Rainfall pulses can significantly drive the evolution of the structure and function of semiarid ecosystems, and understanding the mechanisms that underlie the response of semiarid plants to rainfall is the key to understanding the responses of semi-arid ecosystems to global climatic change. We measured sap flow in the branches and stems of shrubs (Caragana korshinskii Kom. and Hippophae rhamnoides Linn.) using sap flow gauges, and studied the response of sap flow density to rainfall pulses using the "threshold-delay" model in the Chinese Loess Plateau. The results showed that the sap flow began about $1 \mathrm{~h}$ earlier, and increased twofold after rainfall, compared to its pre-rainfall value. The sap flow increased significantly with increasing rainfall classes, then gradually decreased. The response of sap flow was different among rainfall, species, position (branch and stem) during the pulse period, and the interactive effects also differed significantly $(P<0.0001)$. The response pattern followed the threshold-delay model, with lower rainfall thresholds of 5.2, $5.5 \mathrm{~mm}$ and $0.7,0.8 \mathrm{~mm}$ of stem and branch for C. korshinskii and H. rhamnoides, demonstrating the importance of small rainfall events for plant growth and survival in semi-arid regions.
\end{abstract}

Keywords: Rainfall pulses; Sap flow; Meteorological factors; Loess Plateau; Caragana korshinskii; Hippophae rhamnoides.

\section{INTRODUCTION}

Managing scarce fresh surface water resources is becoming an increasingly important environmental, social and economic issue across many regions of the world (Ma et al., 2012; Wang et al., 2011). An understanding of the patterns and behaviour of water use of vegetation can contribute to the effective management of these water resources (Potts et al., 2006). Understanding plant water use is the key for successful ecological restoration in water-limited environments (Chazdon, 2008; Wang et al., 2011). Water is the most important factor limiting ecosystem processes and function in arid and semi-arid regions (Chazdon, 2008; Moran et al., 2009).

Rainfall is a major driver of biological processes in semiarid ecosystems (Cao et al., 2011; Chen et al., 2010; Wang et al., 2010). Sap flow significantly accelerated, and plant transpiration increased, after plants extract the water provided by large rainfall events (Du et al., 2011; Liu et al., 2012), and this triggers a cascade of responses that effects plant growth, reproduction, and net ecosystem productivity (Moran et al., 2009; Ogle and Reynolds, 2004; Rana et al., 2005). Consequently, these events alter the carbon and water balance in the semi-arid ecosystem (Kigalu, 2007), and rainfall pulses could significantly drive the evolution of the structure and function of semi-arid ecosystems (Liu and Zhao, 2008; Reynolds et al., 2004). Understanding the responses of sap flow to rainfall pulses is therefore the basis for comprehending the physiological responses of plants and how these responses determine the ecophysiological patterns of adaptation of plants to their habitats (Klein et al., 2014). The paradigms of resource partitioning such as the Westoby-Bridges theme of 'triggering pulses' (Noy-Meir, 1973) and rooting patterns and resource acquisition (Walter, 1971), have been integrated into a conceptual Threshold-Delay model, proposed by Ogle and Reynolds (2004). The composite model drew on earlier paradigms of resource partitioning (Walter, 1971), thresholds (Sperry, 1986), and pulse responses (Noy-Meir, 1973) to describe the response of differ- ent plants to rainfall in terms of a "threshold-delay" model. This model permits analysis of the effects of individual pulses of rain based on the physiological responses of plants (Cheng et al., 2006; Ogle and Reynolds, 2004). A weakness of the model is that it is empirical rather than mechanistic. Thus, no single parameterized threshold-delay model can be expected to describe every system, and the model must be parameterized for each site. However, many scientists have investigated the responses of the woody, shrub and herbage to rainfall pulses using this model (Ivans et al., 2006; Ogle and Reynolds, 2004; Sponseller, 2007), and their results provided a useful framework for evaluating plant responses to rainfall pulses (Morgan and Barton, 2008; Zeppel et al., 2008).

Rainfall pulses can rapidly increase sap flow and alter the water use efficiency of vegetation (Morgan and Barton, 2008; Zeppel et al., 2008). Some studies have reported that the response of different species to rainfall pulses and plant water use strategies would be various within a given area (Noy-Meir, 1973; Reynolds et al., 2004). For example, shrub species in the Proteaceae, such as Isopogon gardneri rapidly increased their sap flow (by up to 5 times) after $34 \mathrm{~mm}$ of rainfall event in southern Australia, whereas deep-rooted eucalyptus species were sufficiently reliant on antecedent soil condition that they did not respond to precipitation (Amenu and Kumar, 2008; Dawson et al., 2007). These results agreed with those reported by $\mathrm{Xu}$ and $\mathrm{Li}$ (2006) based on studies of the photosynthesis of Haloxylon ammodendron and Tamarix ramosissima. However, the results for the same species may vary within a fixed area. For example, sap flow of Eucalyptus crebra increased rapidly as rainfall increased from 5 to $20 \mathrm{~mm}$ in eastern Australia (Domec et al., 2006; Zeppel et al., 2008), but did not increase under comparable conditions in southern Australia (Stewart and Burgess, 2006). In addition, sap flow varies with respect to water availability in different soil layers (Kurz et al., 2006; Wilson et al., 2001), Nadezhdina et al. (2007) found that sapwood depth of mature olive trees ranged from 22 to $55 \mathrm{~mm}$ with greater variability in trunks than in branches. Studies of 
the response of sap flow to rainfall pulses are scarce around the world, and previous studies have not quantified the response parameters and have only qualitatively described differences between species (Engel et al., 2005; Stewart and Burgess, 2006).

The Loess Plateau in China experiences severe soil erosion, vegetation degradation and desertification (Jiao et al., 2011; Wang et al., 2010). To overcome these problems, extensive vegetation reestablishment practices have been implemented by the Chinese government (Wang et al., 2013; Zhang et al., 2009). Caragana korshinskii Kom. and Hippophae rhamnoides Linn. are the dominant woody species in the Loess Plateau. They are widely used for ecological restoration (Xiao et al., 2011; Zhang et al., 2009). However, the unbalance between water supply and demand is becoming particularly acute because of the initially simple, cultivated vegetation system has developed toward a more complex, cultivated and natural ecosystem capable of reversing desertification (Cao et al., 2011; Jian et al., 2012; Wang et al., 2013). In view of this situation, it is necessary to study the response of sap flow to rainfall pulses. To our knowledge, little is currently known about the response of $C$. korshinskii and H. rhamnoides to rainfall pulses and other environmental conditions. Global climate change appears increasingly likely to increase the variability of rainfall patterns (BassiriRad et al., 1999; Cheng et al., 2006). Therefore, the planted shrubs will be forced to endure repetitive cycles of water scarcity followed by rainfall response (Burgess, 2006; Eberbach and Burrows, 2006). Understanding the mechanisms that underlie the responses of the planted shrubs to rainfall is a key problem in studies of the responses of semi-arid ecosystems with vegetation restoration to global climate change (Blackman and Brodribb, 2011; Blackman et al., 2010; Fravolini et al., 2005; Ivans et al., 2006; Potts et al., 2006; Sponseller, 2007).

In the present study, we investigated the response of these two shrubs to rainfall events by measuring sap flow in their branches and stems using stem flow gauges to examine the different effects of rain pulse size on uptake of rains by the above two dominant shrubs in field conditions. Our aims were to: (1) determine the rainfall threshold required to elicit an increase in shrub water use; (2) understand the relationship between the response of sap flow to rainfall pulses and rainfall amounts, soil moisture, plant water potential and meteorological factors; (3) provide a scientific basis for understanding the mechanisms that underlie the responses of these shrubs to global climatic change.

\section{MATERIALS AND METHODS Site description}

The experiments were conducted in C. korshinskii and H. rhamnoides plantations from June to September 2012 in the Anjiapo catchment, Dingxi County $\left(35^{\circ} 35^{\prime} \mathrm{N}, 104^{\circ} 39^{\prime} \mathrm{E}\right)$ of Gansu province in western Chinese Loess Plateau. The annual mean precipitation is $420 \mathrm{~mm}$ with great seasonal variations. Over $60 \%$ of the precipitation falls between July and September. The average monthly air temperature ranges from -7.4 to $27.5^{\circ} \mathrm{C}$, with mean annual temperature of $6.3^{\circ} \mathrm{C}$. Average annual pan evaporation is $1510 \mathrm{~mm}$. The soil is silt loam of loess origin (Wang et al., 2010), which can be classified as Chernozem according to IUSS Working Group WRB (2006). Land uses in the study area include croplands, grasslands, artificial shrublands and woodlands. A representative C. korshinskii experimental plot and a $H$. rhamnoides experimental plot of $100 \times 100 \mathrm{~m}$ size were selected, and all vegetation and sap flow measurements were conducted inside these two plots. Table 1 showed the basic situation of $C$. korshinskii and $H$. rhamnoides plots.

\section{Weather data}

We installed a meteorological tower in the open area approximately $100 \mathrm{~m}$ from the study site. The meteorological variables were wind speed, air temperature, relative humidity, net and photosynthetically active radiation, rainfall, and atmospheric pressure. These parameters were measured using an AG1000 automatic weather station (Onset Computer Corporation, Pocasset, MA, USA). The sensors were installed at two levels above the ground $(2$ and $3 \mathrm{~m})$. Rainfall was measured with a tipping-bucket rain gauge (model TE525, metric; Texas Electronics, Dallas, TX). Volumetric soil moisture was measured by means of probes (Decagon Devices, Pullman, WA, USA), installed at five depths below the soil surface $(10,20,30,40$ and $50 \mathrm{~cm}$ in the $C$. korshinskii and $H$. rhamnoides woodlands. The meteorological data and volumetric soil moisture were measured at a frequency of $10 \mathrm{~Hz}$ and recorded every 5 min using a CR1000 datalogger (Campbell Scientific Inc., Logan, UT), then stored as the 30-min mean data, whereas rainfall and wind data were stored as the 10 -min mean data. Soil water content was measured every 2 days by means of oven-drying to validate the soil moisture data provided by the probes during the study period.

Table 1. A brief view of sample areas of survey for $C$. korshinskii and $H$. rhamnoides plantations in the Anjiagou catchment.

\begin{tabular}{lllll}
\hline & \multirow{2}{*}{ Parameter } & Sample & \multicolumn{2}{c}{ Mean \pm SD } \\
\cline { 3 - 4 } & numbers & C. korshinskii & H. rhamnoides \\
\hline Geographical parameters & Slope aspect & -- & SE & SE \\
& Slope position & -- & Middle & $191 \pm 17$ \\
\hline Biological parameters & Plant height $(\mathrm{mm})$ & 80 & $1700 \pm 110$ & $1.67 \pm 0.33$ \\
& Basic diameter $(\mathrm{mm})$ & 150 & $15.1 \pm 2.1$ & $3.54 \pm 0.21$ \\
& Projected area $\left(\mathrm{m}^{2}\right)$ & 50 & $3.02 \pm 0.44$ & $0.93 \pm 0.12,1.15 \pm 0.17$ \\
& Leaf area index $(L A I)$ & 320 & $1.04 \pm 0.09,1.58 \pm 0.22$, & $1.87 \pm 0.21,2.15 \pm 0.20$ \\
\hline Soil parameters & & & $2.15 \pm 0.16,2.16 \pm 0.15$ & $11.04 \pm 2.3$ \\
& Clay $(<0.002 \mathrm{~mm} ; \%)$ & 3 & $9.17 \pm 1.20$ & $76.69 \pm 11.34$ \\
& Silt $(0.05-0.002 \mathrm{~mm} ; \%)$ & 3 & $75.59 \pm 9.21$ & $12.27 \pm 2.81$ \\
& Sand $(0.05-2 \mathrm{~mm} ; \%)$ & 3 & $15.24 \pm 1.16$ & $0.71 \pm 0.04$ \\
& Organic matter $(\%)$ & 3 & $0.68 \pm 0.08$ & $7.9 \pm 0.75$ \\
\hline
\end{tabular}

*Slope aspect and slope position were determined by compass; LAI was determined by canopy analyzer (LAI2000, LI-COR, USA) on 14 ${ }^{\text {th }}$ June, $15^{\text {th }}$ July, $15^{\text {th }}$ August and $14^{\text {th }}$ September, the four data in each $L A I$ column is from June to September; Soil organic matter was determined by Potassium dichromate volumetric method; $\mathrm{pH}$ was determined by potentiometry; Particle size distribution was determined by sedimentation. Soil properties are for the top $1 \mathrm{~m}$. 


\section{Sap flow measurements}

We used stem flow gauges (Flow32, Dynamax Inc., Houston, TX, USA) with the energy balance method to measure sap flow in the branches and stems of C. korshinskii and H. rhamnoides. We selected sample branches and stems without lateral ramifications, and smoothed them to remove any superficial bark roughness using a razor blade. To determine the influence of the environment on sap flow differences between species and positions (stem vs. branch) within a species, we attached gauges to branches and the basal stem at least $40 \mathrm{~cm}$ above the soil surface. Based on the measurement scale of the gauges and the characteristics of the shrubs, we used model SGB16 gauges for the branches for $C$. korshinskii and model SGB19 gauges for its stems. We used model SGB13 gauges for the branches of H. rhamnoides, and model 19 gauges for its stems. We used three replicates for each model gauge in each position. Sap flow was measured in a stem and a branch of the same plant.

Table 2. Diameters of the sample shrubs used for the sap flow measurements. Values represent means, with the standard deviation in parentheses $(\mathrm{n}=3)$.

\begin{tabular}{|c|c|c|c|c|}
\hline \multirow[b]{2}{*}{$\begin{array}{l}\text { Gauge } \\
\text { type }\end{array}$} & \multicolumn{2}{|l|}{ C. korshinskii } & \multicolumn{2}{|c|}{ H. rhamnoides } \\
\hline & $\begin{array}{l}\text { SGB16 } \\
\text { (branch) }\end{array}$ & $\begin{array}{l}\begin{array}{l}\text { SGB19 } \\
\text { (stem) }\end{array} \\
\end{array}$ & $\begin{array}{l}\text { SGB13 } \\
\text { (branch) }\end{array}$ & $\begin{array}{l}\begin{array}{l}\text { SGB19 } \\
\text { (stem) }\end{array} \\
\end{array}$ \\
\hline $\begin{array}{l}\text { Diameter } \\
(\mathrm{mm})\end{array}$ & $15.91 \pm 0.20$ & $19.11 \pm 0.19$ & $13.51 \pm 0.48$ & $19.54 \pm 0.32$ \\
\hline
\end{tabular}

Table 2 presented the diameters of the sampled shrubs. The theoretical method and methodology of sap flow gauging have been described previously by Smith and Allen (1996) and Yue et al. (2008), and we carefully installed the gauges following the manufacturer's instructions. We prepared the branch and stem surfaces by sanding, and installed the gauges with a layer of G4 silicon grease between the gauge and the bark. We wrapped the gauges in aluminum foil to shield them from rain and direct solar radiation, so as to reduce extraneous thermal gradients across the heated section. Shelters were attached above the gauges, and the joints were sealed with wax to prevent water from flowing down the branches and stems into the gauges (Yue et al., 2008). The data were recorded at 10-s intervals and stored as 30-min averages using a CR1000 datalogger (Campbell Scientific, Logan, UT, USA). This study used the stem heat balance basics described in detail by Kigalu (2007), and the energy balance is expressed as:

$Q_{f}=P_{i n}-Q_{c d}-Q_{r}+Q_{s}$

where $Q_{f}$ is the amount of heat (W) transported in the moving sap; $P_{\text {in }}$ is the heater power input $(\mathrm{W}) ; Q_{c d}$ is the heat conduc- tion loss along the stem up and down stream (W); $Q_{r}$ is the radial heat conduction loss $(\mathrm{W}) ; Q_{s}$ is the heat stored in the stem section (W).

The sap flow density $\left(\mathrm{kg} \mathrm{m}^{-2} \mathrm{~h}^{-1}\right)$ was calculated from the energy balance across the sap flow meter which states that:

$$
F=\frac{P_{i n}-Q_{c d}-Q_{r}+Q_{s}}{C_{s} \times d T_{\text {sap }}}
$$

where, $C_{s}$ is the specific heat capacity of the sap or water $\left(4.186 \mathrm{~J} \mathrm{~g}^{-1} \mathrm{C}^{-1}\right)$; $d T_{\text {sap }}$ is the temperature differential between the heater and the stem section $\left({ }^{\circ} \mathrm{C}\right)$. The sum of sap flow density in each hour is the daily sap flow density.

\section{Water potential measurements}

We cut the leaves, stems and branches (leaves were in the measured stems and branches) from the plants which were selected to measure the sap flow (did not disturb the stems and branches where gauges were installed) (Fig. 1). Three pressure chambers (Model 600, Plant Water Status Console, Soil Moisture Equipment Corporation, USA) were used to measure stem and branch water potential and three dew point water potential equipments (WP4C, Decagon company, USA) to measure leaf water potential to guarantee the synchronicity of the measurements. We used three replicates for each measurement. Measurements were carried out weekly from 8:00 to 20:00 at $1 \mathrm{~h}$ intervals during the experimental period. We also measured the plant water potentials (leaves, stems and branches) after rainfall events.

Leaf hydraulic conductance $\left(K_{\text {leaf }}\right)\left(\mathrm{mmol} \mathrm{m} \mathrm{m}^{-2} \mathrm{~s}^{-1} \mathrm{MPa}^{-1}\right)$ was determined using a timed rehydration method described in Brodribb and Holbrook (2003), which is based on an analogy between rehydrating a leaf and recharging a capacitor:

$$
K_{\text {leaf }}=C \ln \left(\psi_{o} / \psi_{f}\right) / t
$$

where $C=$ capacitance, $\Psi_{o}=$ leaf water potential prior to partial rehydration, $\Psi_{f}=$ leaf water potential after partial rehydration and $t=$ duration of rehydration. Values of $C$ were estimated from pressure-volume curves using the methods described by Brodribb and Holbrook (2003). Briefly, the leaf water potential corresponding to turgor loss was estimated as the inflection point of the graph of leaf water potential vs. relative water content (RWC). The slope of the curve prior to, and following, turgor loss provided $C$ in terms of RWC $\left(C_{r w c}\right)$ for pre-turgor loss and post-turgor loss, respectively. Five to six leaves of each species were used to construct pressure-volume curves and estimate $C$.
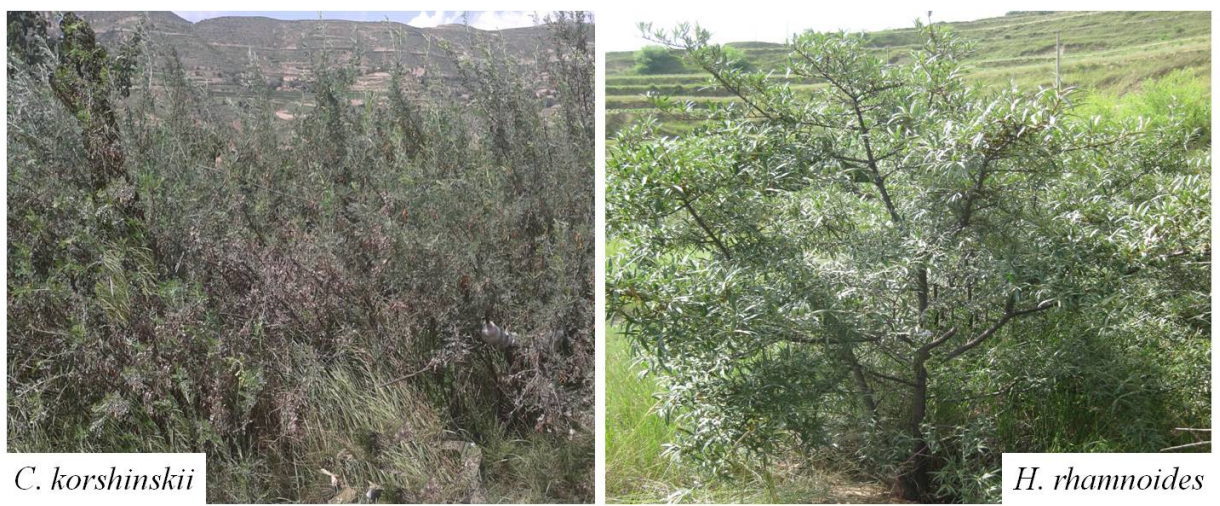

Fig. 1. Photographs showing the two shrubs of $C$. korshinskii and H. rhamnoides in the study. 


\section{Data analysis}

The threshold-delay model analyzed the effect of individual pulses of rain based on the physiological responses of the plants (Ogle and Reynolds, 2004). It is based on six parameters that capture the nonlinear nature of plant responses to rainfall pulses. The rate of a plant's response to rainfall pulses can vary based on species or plant functional types, the delay in the timing of physiological responses, the effect of antecedent moisture and physiological conditions, and precipitation thresholds (Zeppel et al., 2008). The model incorporates how quickly a plant responds, the magnitude of the response, the duration of the response, and the thresholds of the response, or no further response, is evident. The model can be expressed as follows (Ogle and Reynolds, 2004):

$$
\begin{aligned}
& y_{t}=k y_{t-1}+\delta_{t} \\
& \delta_{t}=\operatorname{Min}\left[y_{\text {max }}(1-k), \delta_{t}^{*}\left(1-\frac{y_{t-1}}{y_{\max }}\right)\right] \\
& \delta_{t}^{*}= \begin{cases}\frac{\delta_{\max }}{R^{U}-R^{L}}\left(R_{t-\tau}-R^{L}\right) & R^{L}<R_{t-\tau}<R^{U} \\
0 & R_{t-\tau} \leq R^{U} \\
\delta_{\max } & R_{t-\tau} \geq R^{U}\end{cases}
\end{aligned}
$$

where, $y_{t}$ is the variable (e.g., plant transpiration), $y_{t-1}$ is the antecedent value of this variable, $y_{\max }$ is the maximum response value, $\delta_{t}$ is the response variable, $\delta_{t}^{*}$ is the potential response variable, $\delta_{\max }$ is the maximum potential response variable, $R^{L}$ is the lower rainfall threshold, $R^{U}$ is the upper rainfall threshold, $R_{t-\tau}$ is the efficient rainfall, $\tau$ is the time lag, $t$ is the response time, and $k$ is the reduction rate.

The threshold rainfall size was determined using ANOVA and Tukey's HSD test (after testing for homogeneity of variance and normal distribution). The threshold was identified as the lowest rainfall event to be significantly different from the 0-5 mm rainfall class (Statistica version 8), conceptually similar to a method commonly used in ecotoxicology studies to identify the lowest observed effect concentration (Salleo et al., 2001). Data were excluded for the following situations, to comply with the characteristics of a rainfall pulse: when rainfall events lasted longer than 5 days or interpulse periods lasted less than 1 week. We determined the parameters of the threshold delay model by means of multiple linear regression. Also, the multiple linear regressions (SPSS v18.0 for Windows) were used to explore the unique contribution of each predictor in explaining the variance of the dependent variable.

\section{RESULTS \\ Rainfall and soil moisture}

Rainfall data for the study region were collected from 1997 to 2012. The results indicated that the annual rainfall averaged $352.1 \mathrm{~mm}$, with the following distribution of rainfall: $\leq 5 \mathrm{~mm}$, $30.1 \%$ of annual rainfall amount and $57.2 \%$ of the events; $5.1-$ $10 \mathrm{~mm}, 20.3 \%$ and $13.4 \%$, respectively; $10.1-15 \mathrm{~mm}, 17.6 \%$ and $8.4 \% ; 15.1-20 \mathrm{~mm}, 10.4 \%$ and $11.6 \% ; 20.1-25 \mathrm{~mm}, 7.1 \%$ and $6.7 \%$; $>25 \mathrm{~mm}, 14.5 \%$ and $9.7 \%$ (Fig. 2A). The percentages of the total amount and frequency of events decreased with increasing rainfall during the experimental period. Small events ( $\leq 5 \mathrm{~mm}$ ) were most frequency, whereas larger events $(\geq 10 \mathrm{~mm}$ ) were infrequent but had a greater influence on total rainfall (Fig. 2B). During the experimental period, there were
36 rainfall events, which produced a total rainfall of $268 \mathrm{~mm}$ and an average rainfall of $7.4 \mathrm{~mm}$, with individual events ranging from 0.1 to $27.3 \mathrm{~mm}$.

Soil water content from 0 to $10 \mathrm{~cm}$ was the highest and fluctuated significantly with increasing rainfall with $40.2 \%$ and $44.5 \%$ of the variation coefficient for C. korshinskii and $H$. rhamnoides. Rainfall had an effect on the soil water content at $10 \mathrm{~cm}$ depth more frequently than other three soil depths. Soil water content and variation coefficient in deeper soil layers were relatively low (Fig. 3C and D). Soil water content at $10 \mathrm{~cm}$ depth responded to rain events if the cumulative rainfall total over a 3-5 day period exceeded $10-12 \mathrm{~mm}$. Single rain events of less than $10 \mathrm{~mm}$ had little effect on soil water content at $20 \mathrm{~cm}, 30 \mathrm{~cm}, 40 \mathrm{~cm}$ or $50 \mathrm{~cm}$ depth (Fig. $3 \mathrm{C}$ and D).

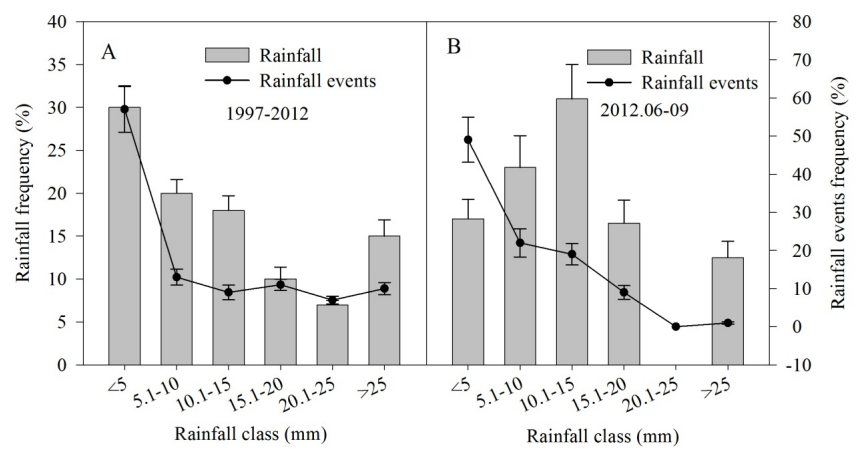

Fig. 2. The frequency distribution of the rainfall and rainfall events during 15 years (A) and period of measurements (B).

\section{Rainfall response}

Diurnal variation in sap flow responses

The diurnal variation in sap flow density in branches and stems showed a trend of first increase and then decrease, and started to increase just after midnight (Fig. 4). Sap flow density in the stems of $C$. korshinskii began about $1 \mathrm{~h}$ earlier after rainfall, and the mean sap flow density increased to 1.82 times its pre-rainfall value of $72.9 \mathrm{~kg} \mathrm{~m}^{-2} \mathrm{~h}^{-1}$ (Fig. 4A). The daytime averaged sap flow density in the branches of C. korshinskii is $43.19 \mathrm{~kg} \mathrm{~m}^{-2} \mathrm{~h}^{-1}$ before rainfall, but began about $2 \mathrm{~h}$ earlier after rainfall, with sap flow density as a daytime average increasing to 2.44 times its pre-rainfall value (Fig. 4B). For the stems of $H$. rhamnoides, sap flow density began about $1 \mathrm{~h}$ earlier after rainfall, the daytime averaged sap flow density is $50.14 \mathrm{~kg}$ $\mathrm{m}^{-2} \mathrm{~h}^{-1}$ before rainfall, which increased to 1.84 times its prerainfall value after rainfall (Fig. 4C). Sap flow density in the branches of $H$. rhamnoides was at a daytime mean value of $27.55 \mathrm{~kg} \mathrm{~m}^{-2} \mathrm{~h}^{-1}$, but began slowly increasing about $1.5 \mathrm{~h}$ earlier after rainfall and sap flow density as a daytime average increased to 2.31 times its pre-rainfall value (Fig. 4D). Based on these results, sap flow density in the branches of $C$. korshinskii showed the largest response to rainfall pulses, followed by sap flow density in $H$. rhamnoides branches, $H$. rhamnoides stems, and C. korshinskii stems.

\section{Daily variation in the response of sap flow}

The response differed significantly among precipitation, species, positions, and pulses durations (Table 3). The species $\times$ position $\times$ pulse duration and rainfall $\times$ species $\times$ position $\times$ pulse duration interactions were significant, which means that sap flow in these planted shrubs responds significantly to rainfall pulses. 


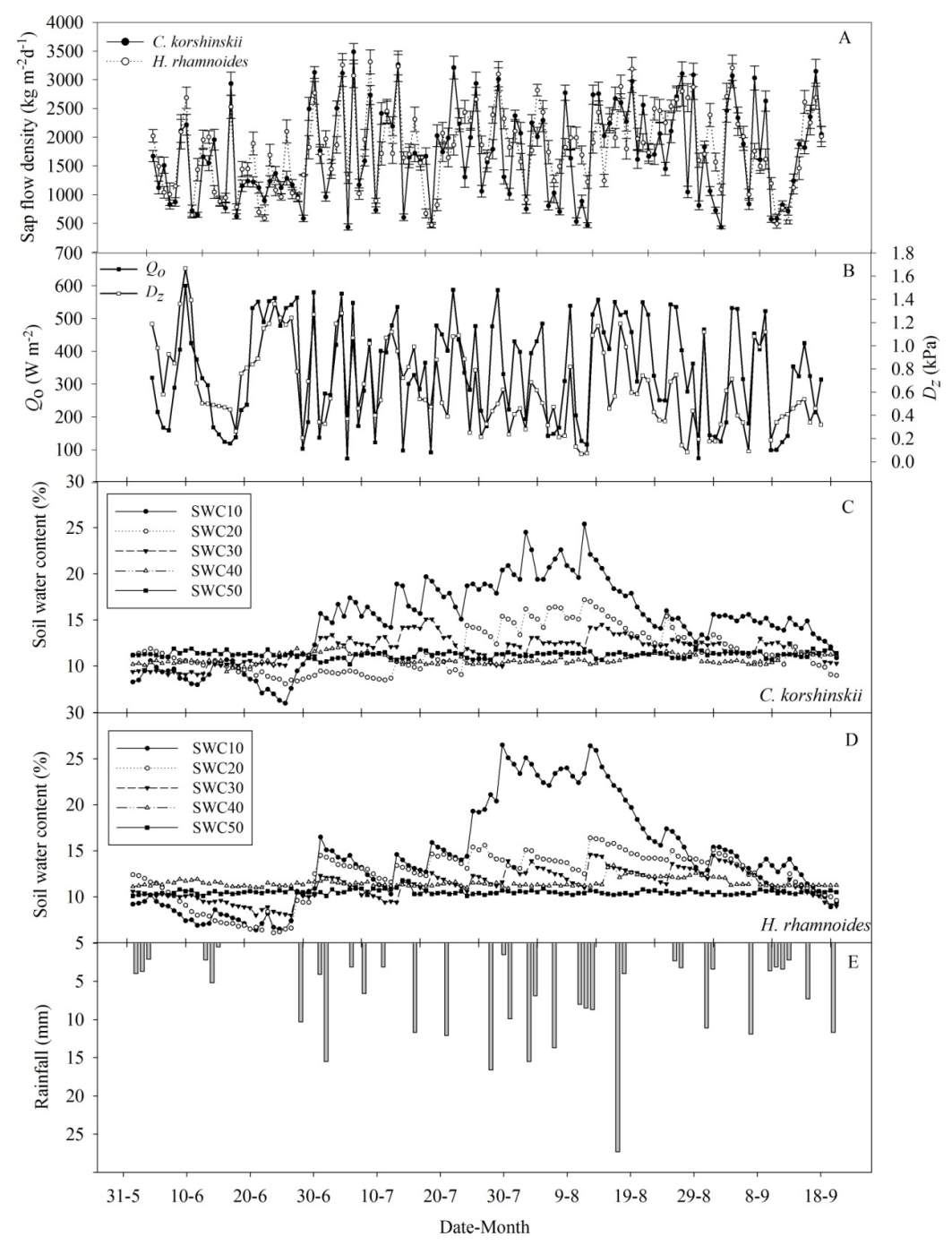

Fig. 3. Daily values for A, sap flow during whole experiment period ( $1^{\text {st }}$ June to $30^{\text {th }}$ September), data represent the mean values of each stem and branch for $C$. korshinskii and H. rhamnoides; B, Vapor pressure deficit $\left(D_{z}\right)$ and photosynthetically active radiation $\left(Q_{\mathrm{o}}\right)$; C and D, the dynamic variation of rainfall pulses; E, rainfall. SWC10, SWC20, SWC30, SWC40 and SWC50 are soil water content (\%) at 10, 20, 30, 40 and $50 \mathrm{~cm}$ below the soil surface, respectively.

Table 3. Results of General lineal Model Repeated measures by means of multi-way within-subject designs.

\begin{tabular}{lll}
\hline Factor & $F$ value & $P$ value \\
\hline Rainfall & 18.59 & $0.000^{* * *}$ \\
Species & 44.66 & $0.000^{* * *}$ \\
Position & 83.11 & $0.000^{* * *}$ \\
Pulse duration & 16.94 & $0.000^{* * *}$ \\
Species $\times$ Position & 314.73 & $0.000^{* * *}$ \\
Rainfall $\times$ Position & 16.11 & $0.001^{* *}$ \\
Rainfall $\times$ Species & 11.22 & $0.000^{* * *}$ \\
Rainfall $\times$ Species $\times$ Position & 15.62 & $0.001^{* *}$ \\
Species $\times$ Pulse duration & 2.31 & $>0.05$ \\
Rainfall $\times$ Pulse duration & 22.45 & $0.000^{* * *}$ \\
Rainfall $\times$ Species $\times$ Pulse duration & 1.06 & $>0.05$ \\
Position $\times$ Pulse duration & 1.19 & $>0.05$ \\
Species $\times$ Position $\times$ Pulse duration & 10.23 & $0.000^{* * *}$ \\
Rainfall $\times$ Position $\times$ Pulse duration & 0.87 & $>0.05$ \\
Rainfall $\times$ Species $\times$ Position $\times$ Pulse duration & 6.24 & $0.025^{*}$ \\
\hline
\end{tabular}

Significance differences $* p<0.05 ; * * p<0.01 ; * * * p<0.001$

In most cases, higher sap flow densities coincided with higher values of daily photosynthetically active radiation $\left(Q_{\mathrm{o}}\right)$ and mean daily vapor pressure deficit $\left(D_{z}\right)$ normalized by daylight hours (Fig. 3). Such as $30^{\text {th }}$ June and $15^{\text {th }}$ July, sap flow densities were $3129.88,2772.81 \mathrm{~kg} \mathrm{~m}^{-2} \mathrm{~d}^{-1}$ and 3264.04 , $3234.32 \mathrm{~kg} \mathrm{~m}^{-2} \mathrm{~d}^{-1}$ for $C$. korshinskii and H. rhamnoides. Water demand was low as a result of low $Q_{\mathrm{o}}$ and $D_{z}$. Such as $14^{\text {th }}$ June and $5^{\text {th }}$ September, sap flow densities were $923.11,1140.24 \mathrm{~kg}$ $\mathrm{m}^{-2} \mathrm{~d}^{-1}$ and $552.15,571.24 \mathrm{~kg} \mathrm{~m}^{-2} \mathrm{~d}^{-1}$ for C. korshinskii and $H$. rhamnoides. On days when rain occurred resulted in low $Q_{\mathrm{o}}$ and $D_{z}$, sap flow densities were greatly reduced. On $11^{\text {st }}$ July the sudden rainfall occurred with associated low $Q_{\mathrm{o}}$ and $D_{z}$, sap flow densities were 880.04 and $1073.43 \mathrm{~kg} \mathrm{~m}^{-2} \mathrm{~d}^{-1}$ for $C$. korshinskii and $H$. rhamnoides. However, on some rainy days followed by high $Q_{\mathrm{o}}$ and $D_{z}$ such as $28^{\text {th }}$ June, $21^{\text {st }}$ July and $18^{\text {th }}$ August had relatively high sap flow densities. Daily patterns of transpiration of $C$. korshinskii and H. rhamnoides showed relatively low values in middle to late June, experienced with 12 days dry period, although $Q_{\mathrm{o}}$ and $D_{z}$ remained higher values (Fig. 3). The percentage response of sap flow increased significantly with increasing rainfall classes $(P<0.05)$, then gradually decreased (Fig. 5) for C. korshinskii and H. rhamnoides. The response differed significantly among rainfall classes and species. It showed that low $R^{2}$ values between sap flow and $Q_{0}$ and $D_{z}$ in June and September. Sap flow was significantly influ- 

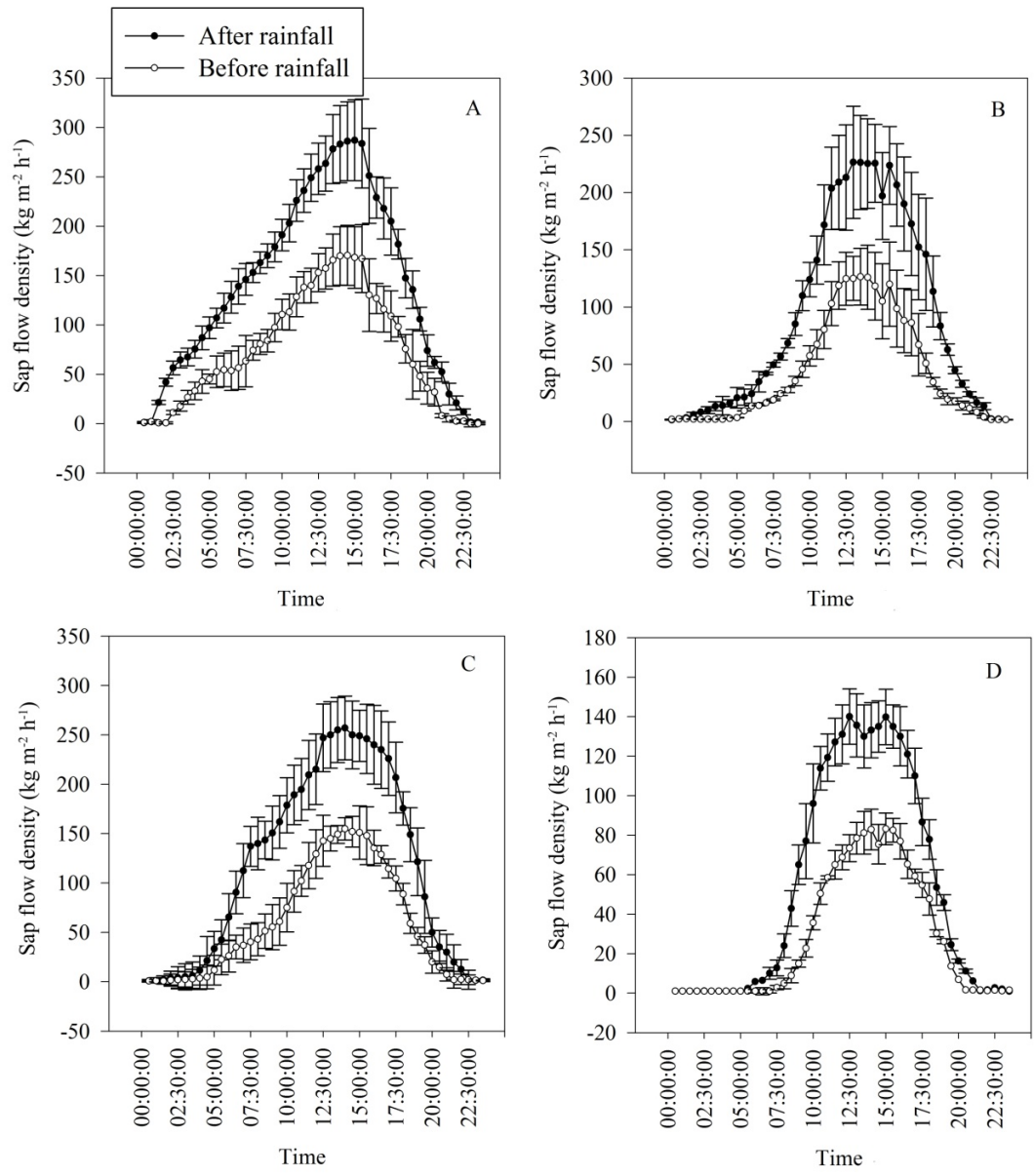

Fig. 4. The diurnal variation in the response of sap flow to rainfall pulses. A, stems and B, branches of C. korshinskii; C, stems and D, branches of $H$. rhamnoides. Before rainfall represent the day before a rainfall event, and after rainfall represent the day from the rainfall day to the time when the maximum occurred after the rain. The data $=$ mean $\pm \mathrm{SD}$, the mean data presented the sap flow of the day before and after rainfall of all rainfall events.

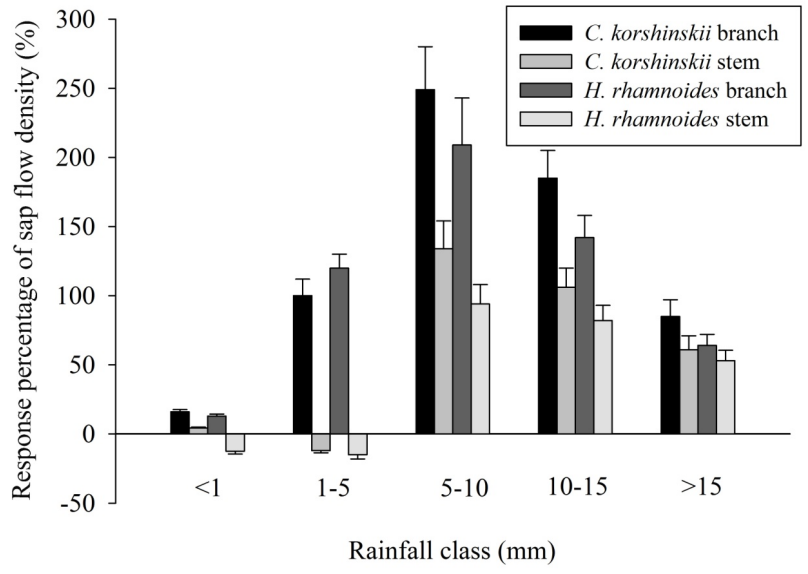

Fig. 5. The response of sap flow density to rainfall class. Values represent the mean \pm SD change in sap flow from the first day before a rainfall event to the first day after a rainfall event (Tukey's HSD test, $P<0.05)$.

enced by $Q_{0}$ and $D_{z}$ for $C$. korshinskii and $H$. rhamnoides in July and August (Fig. 6).

We also calculated the rainfall threshold by ANOVA and Tukey's HSD test, and determined the parameters of the threshold-delay model by means of multiple linear regression
(Table 4). The lower rainfall thresholds for stem of C. korshinskii and $H$. rhamnoides were 5.2 and $5.5 \mathrm{~mm}$, and the lower thresholds of rainfall for branch appeared after 0.7 and $0.8 \mathrm{~mm}$, respectively. The upper rainfall thresholds for stem in the two shrubs were 13.1 and $12.4 \mathrm{~mm}$, and the upper thresholds of branch occurred after 3.9 and $5.9 \mathrm{~mm}$ of rainfall for C. korshinskii and $H$. rhamnoides, respectively.

The multiple linear regression of sap flow density $\left(J_{s}\right)$ in each month of $C$. korshinskii and $H$. rhamnoides with the $D_{z}$, $Q_{0}$, air temperature $\left(T_{a}\right)$ and potential evapotranspiration $\left(E T_{0}\right)$ was programmed by SPSS using the stepwise regression method (Table 5). The results showed that the $J_{s}$ in $C$. korshinskii and $H$. rhamnoides was the result of the $D_{z}, Q_{\mathrm{o}}$ and $T_{a}$ in August, and the $J_{s}$ mainly depended on the $D_{z}$. But the $J_{s}$ was the result of the $D_{z}$ and $Q_{\mathrm{o}}$ in other months.

\section{Response of sap flow to plant water potential and $\boldsymbol{K}_{\text {leaf }}$}

In general, the diurnal variation in water potential drops in leaves and branches and stems showed a trend of first increase and then decrease. Water potential drops in the leaves and stems of C. korshinskii averaged $0.34 \mathrm{MPa}$ before rainfall, but after rainfall, with water potential drops as a daytime average increased to 1.62 times its pre-rainfall value (Fig. 7A). The mean water potential drops in leaves and branches of $C$. korshinskii increased to 1.51 times its pre-rainfall value of 0.26 $\mathrm{MPa}$ (Fig. 7B). However, the negative values of water potential 

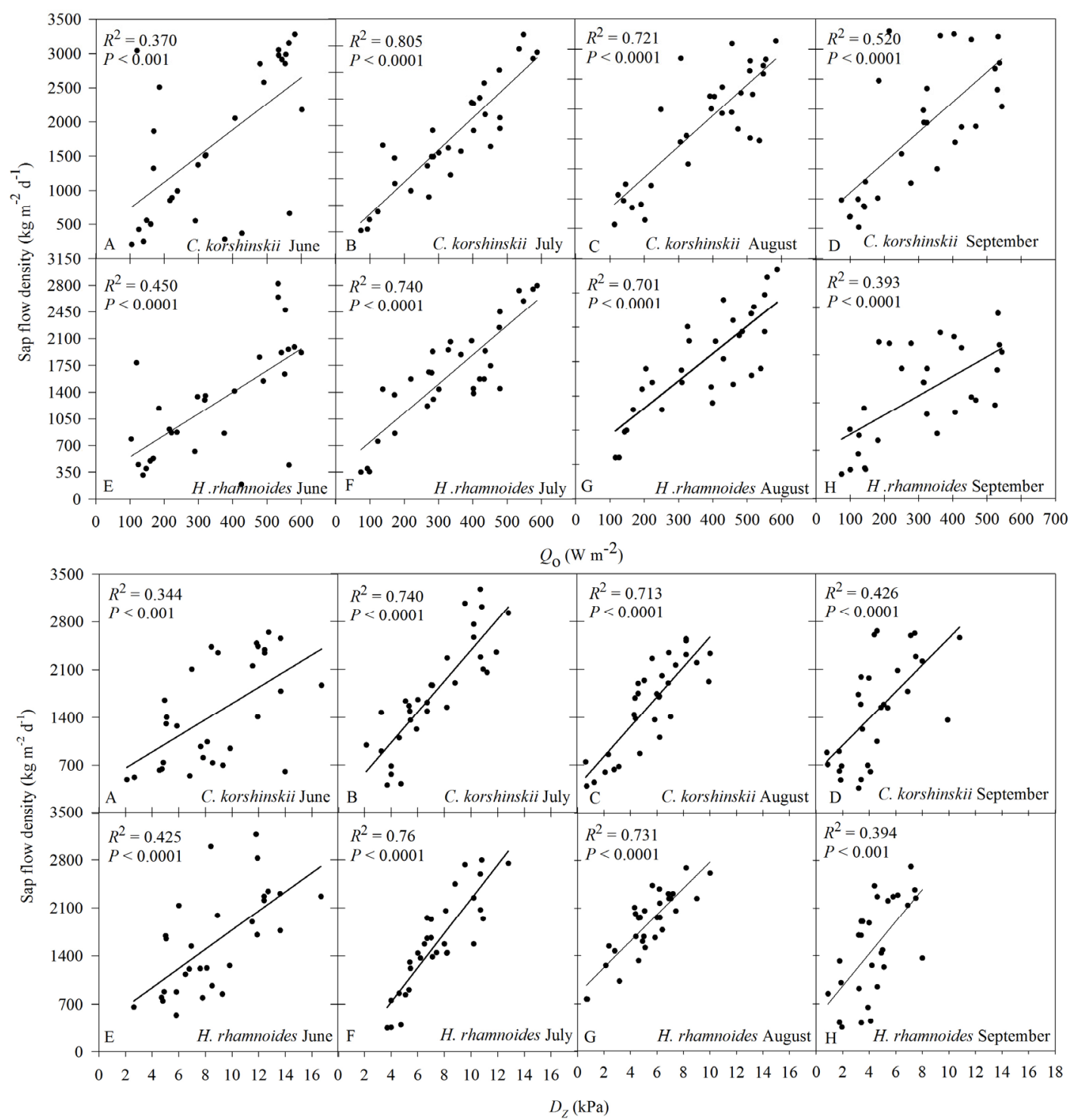

Fig. 6. Relationship between daily sap flow and mean daily vapor pressure deficit $\left(D_{z}\right)$ and daily sums of photosynthetically active radiation $\left(Q_{0}\right)$ in June, July, August and September 2012 for C. korshinskii and H. rhamnoides, respectively. Data represent the mean values of each stem and branch for $C$. korshinskii and H. rhamnoides.

Table 4. The parameters of the threshold-delay model for changes in sap flow in response to rainfall pulses. $R^{L}$ and $R^{U}$ are the lower and upper thresholds of rainfall (respectively), $k$ is the reduction rate in the absence of significant rainfall, and $\tau$ is the time lag.

\begin{tabular}{llllll}
\hline Species & Position & $R^{L}(\mathrm{~mm})$ & $R^{U}(\mathrm{~mm})$ & $k$ & $\tau$ (day) \\
\hline C. korshinskii & Stem & 5.20 & 13.1 & 0.80 & 4.21 \\
& Branch & 0.70 & 3.90 & 1.16 & 4.43 \\
H. rhamnoides & Stem & 5.50 & 12.4 & 0.77 & 5.16 \\
& Branch & 0.80 & 5.90 & 1.16 & 4.94 \\
\hline
\end{tabular}

in leaves and stems existed from 13:00 to 16:00 for H. rhamnoides before rainfall, and that increased rapidly after rainfall. Water potential drops in the branches of $H$. rhamnoides followed a similar pattern to that of $C$. korshinskii branches, but water potential drops increased to only1.21 times its pre-rainfall value after rainfall.The morning leaf water potentials were between -1.06 and $-1.98 \mathrm{MPa}$ in stems and branches for the two species before and after rainfall and declined to minima of -1.98 to $-3.02 \mathrm{MPa}$ by midday (Fig. 8). Before rainfall, daily reductions in $K_{\text {leaf }}$ were observed in stems and branches for all two species (Fig. 8A-D). Especially, stem of H. rhamnoides had a complete loss of $K_{\text {leaf }}$ by late afternoon but recovered slightly by the end of the measurement period. After rainfall, $K_{\text {leaf }}$ in stems of $C$. korshinskii and $H$. rhamnoides tended to be stable (Fig. 8E and G) and the increments in $K_{\text {leaf }}$ were found in branches of the two species during the daily course (Fig. 8F and $\mathrm{H})$.

\section{DISCUSSION \\ Response of sap flow to soil water content}

Rainfall input at the soil surface triggered an infiltration pulse of soil moisture, particularly in semi-arid regions (Chen et al., 2010). Generally, large rainfall events lead to larger pulses, whereas small events may only be able to wet the uppermost soil layers, where a large fraction of the soil moisture is lost by direct evaporation. Rainfall of $1 \mathrm{~mm}$ or less had little impact on soil water content (Fig. 3C, D and E) as a result of the strong evaporative demand in the study area, which agreed with the results reported by $\mathrm{Cao}$ et al. (2011). There is considerable debate about the importance of these small events $(<5 \mathrm{~mm})$ to plant growth and survival (Cao et al., 2011). Some studies had 

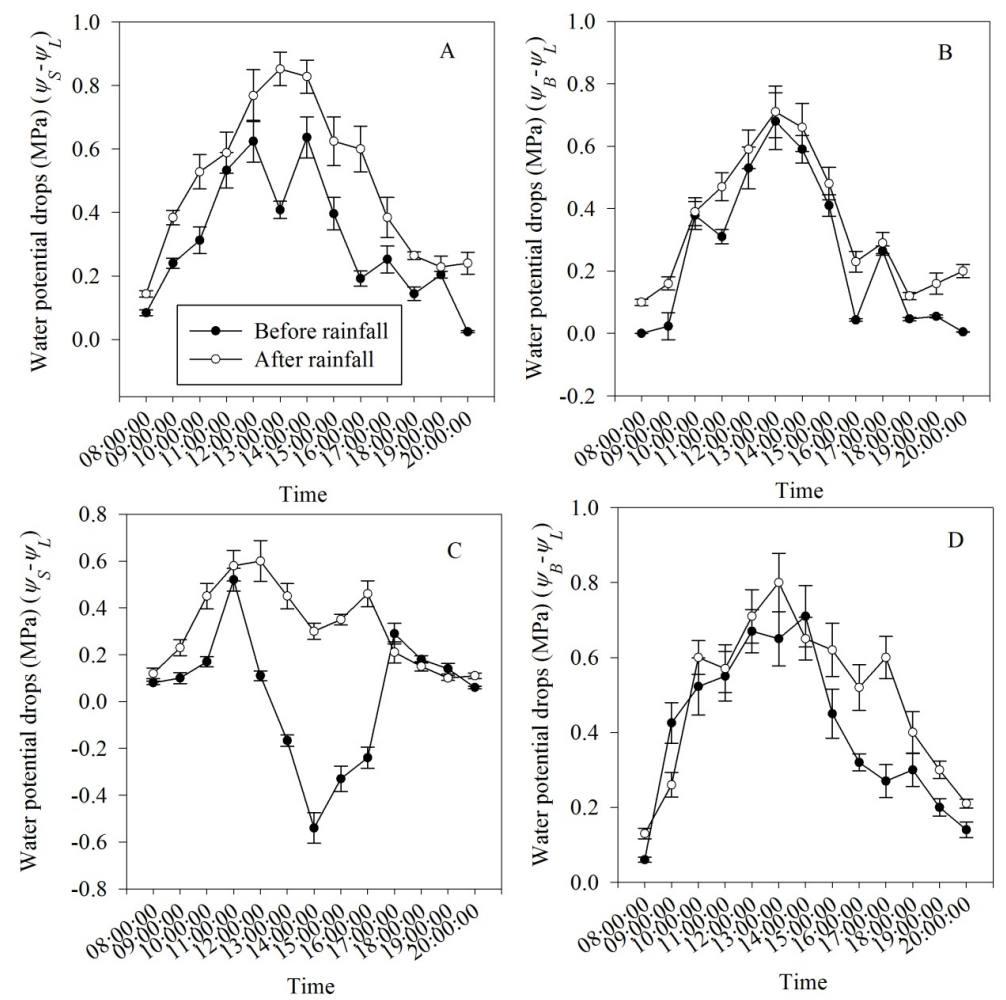

Fig. 7. The diurnal variation in the response of water potential drops to rainfall pulses. A, stems and B, branches of C. korshinskii; C, stems and $\mathrm{D}$, branches of $H$. rhamnoides. Before rainfall represent the day before a rainfall event. $\Psi_{S}$, stem water potential; $\Psi_{B}$, branch water potential; $\Psi_{L}$, leaf water potential.

Table 5. The multiple linear correlation equations between daily sap flow density and environmental factors in each month $\left(1^{\text {st }} \mathrm{June}-30^{\text {th }}\right.$ September 2012) for C. korshinskii and H. rhamnoides.

\begin{tabular}{|c|c|c|c|c|c|}
\hline Species & Month & Regression equations & $R^{2}$ & $F$ & Sampled number (n) \\
\hline \multirow{4}{*}{$\begin{array}{l}\text { C. } \\
\text { korshinskii }\end{array}$} & June & $J_{s}=2.034+0.502 D_{z}+1.345 \times 10^{-3} Q_{\mathrm{o}}$ & 0.806 & 60.234 & 30 \\
\hline & July & $J_{s}=2.037+0.366 D_{z}+1.215 \times 10^{-3} Q_{\mathrm{o}}$ & 0.824 & 55.122 & 31 \\
\hline & August & $J_{s}=3.345+0.157 D_{z}+1.005 \times 10^{-3} Q_{0}-8.64 \times 10^{-2} T_{a}$ & 0.836 & 50.475 & 31 \\
\hline & September & $J_{s}=1.976+0.119 D_{z}+2.034 \times 10^{-3} Q_{\mathrm{o}}$ & 0.791 & 63.120 & 30 \\
\hline \multirow{4}{*}{$\begin{array}{l}H . \\
\text { rhamnoides }\end{array}$} & June & $J_{s}=0.543+0.621 D_{z}+1.522 \times 10^{-3} Q_{\mathrm{o}}$ & 0.778 & 59.123 & 30 \\
\hline & July & $J_{s}=1.132+0.843 D_{z}+2.573 \times 10^{-3} Q_{0}$ & 0.812 & 73.271 & 31 \\
\hline & August & $J_{s}=2.188+0.331 D_{z}+1.324 \times 10^{-3} Q_{0}-1.231 \times 10^{-2} T_{a}$ & 0.835 & 63.121 & 31 \\
\hline & September & $J_{s}=4.239+0.662 D_{z}+1.041 \times 10^{-3} Q_{0}$ & 0.860 & 59.683 & 30 \\
\hline
\end{tabular}

*The dependent variable is sap flow density $\left(J_{s}\right)$, the independent variables were daily vapor pressure deficit $\left(D_{z}\right)$, daily photosynthetically active radiation $\left(Q_{\mathrm{o}}\right)$, air temperature $\left(T_{a}\right)$, soil water content $(S W)$ and potential evapotranspiration $\left(E T_{0}\right)$. Significant difference $(P<0.05)$.

reported that small rainfall events cannot reach the roots of plants (e.g., Du et al., 2011). However, Schwinning et al. (2003) reported that every addition of approximately $1 \mathrm{~mm}$ increased the pulse duration for infiltration amounts between 2 and $20 \mathrm{~mm}$ in the Colorado Plateau.

Sponseller (2007) reported that small rainfall events stimulated the growth of grasses in semi-arid regions and concluded that small amounts of rain may provide a shallow source of moisture that is conducive to some plants. Our previous study had reported that $C$. korshinskii and $H$. rhamnoides showed greater potential to use stemflow water in the semi-arid regions (Jian et al., 2014). The results showed that soil moisture increased in upper $30 \mathrm{~cm}$ of the soil for 2-3 days (Fig. 3C, D and E). Sap flow of branches in C. korshinskii increased rapidly after $3.9 \mathrm{~mm}$ of rain, but its maximum of sap flow reached after about four days. This indicated that even small events $(<5 \mathrm{~mm})$ are not only important for plant growth and survival in semiarid regions, but also that the response are characterized by a lag (Table 4). Ježík et al. (2015) found that a large rainfall event wetted the soil profile to a depth of $100 \mathrm{~cm}$ and improved the soil water status for several weeks in Norway spruce, European. Our results showed that large events are most likely to produce soil moisture recharge at sufficient depth to induce and maintain a significant soil moisture response (Fig. 3C and D), leading to a rapid response by sap flow in the stem.

Resource pulses induce a hierarchy of ecological responses to rainfall events (Schwinning et al., 2003). A larger cumulative effect is produced when soil moisture responds to frequent, small events; as a result, the response amount and pulse duration for soil moisture after consecutive rainfall of 4, 3.7, and 2.1 $\mathrm{mm}$ was considerably higher than the corresponding changes after a single rainfall of $10.3 \mathrm{~mm}$ (Fig. 3C, D and E). Therefore, sap flow after the $27.1 \mathrm{~mm}$ rainfall was lower than the response after the $7.9 \mathrm{~mm}$ (Fig. 3), since the latter rainfall event preceded by two smaller events. Plant responses to "biologically important" rainfall events is related to the water sources exploited 

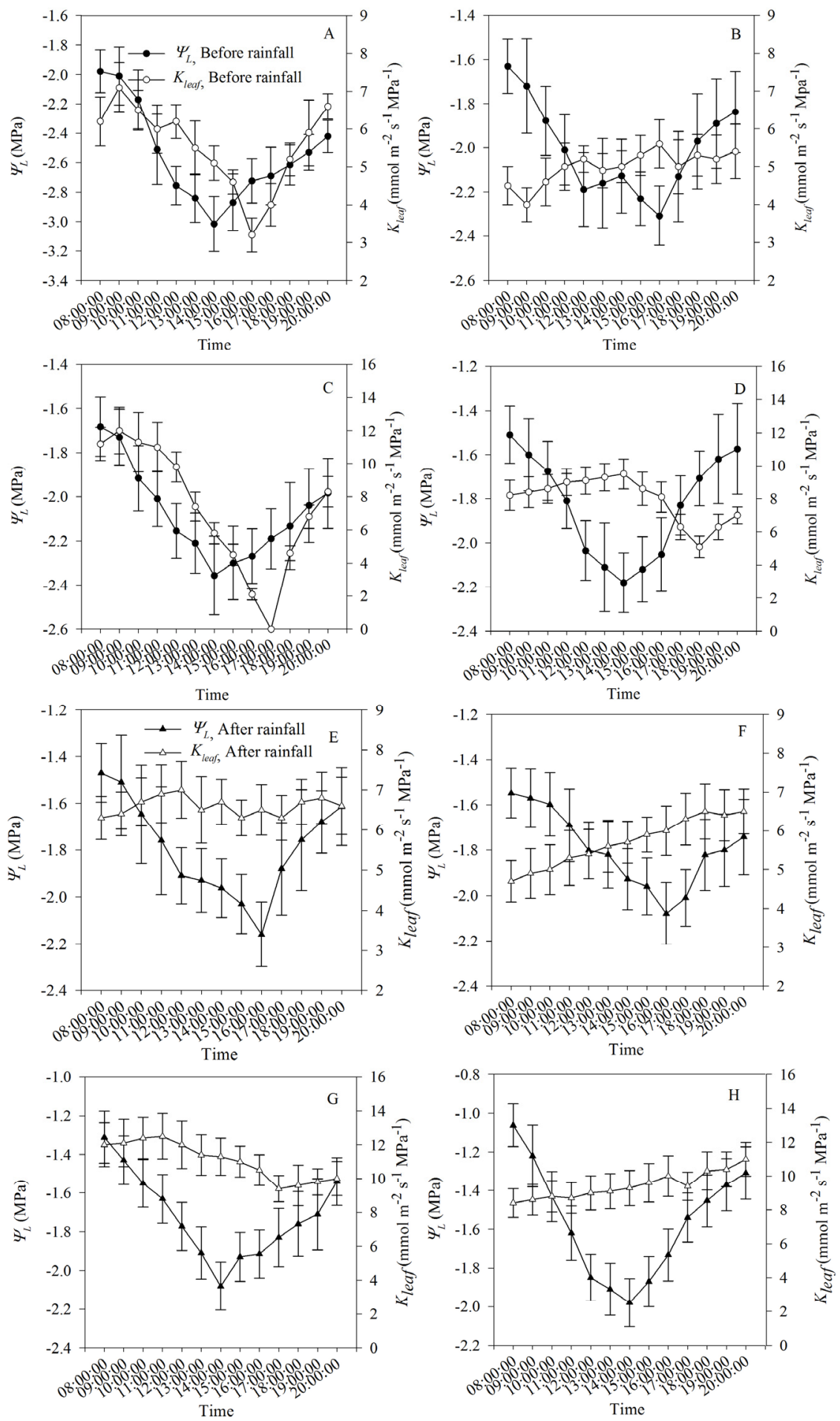

Fig. 8. The diurnal variation of leaf water potential $\left(\Psi_{L}\right)$ and $K_{\text {leaf }}$ in stems and branches before and after rainfall. A, leaves in stems and B, leaves in branches of $C$. korshinskii before rainfall; $\mathrm{C}$, leaves in stems and $\mathrm{D}$, leaves in branches of $H$. rhamnoides before rainfall; $\mathrm{E}$, leaves in stems and $\mathrm{F}$, leaves in branches of $C$. korshinskii after rainfall; $\mathrm{G}$, leaves in stems and $\mathrm{H}$, leaves in branches of H. rhamnoides after rainfall. Data $=$ mean \pm SD.

by the plants and to the importance of seasonality, plant phenology, plant age, and antecedent conditions (Reynolds et al., 2004). For example, the response of sap flow was not significant after a $8.3 \mathrm{~mm}$ rainfall on $17^{\text {th }}$ September (Fig. 3), since the antecedent soil water content was higher owing to consecutive rainfall of $3.6,3.1,3.4$ and $2.2 \mathrm{~mm}$ from $11^{\text {th }}$ to $14^{\text {th }} \mathrm{Sep}$ tember, and the physiological function of the plants was declined because this rain fell during a late growth stage.

\section{Response of sap flow to rainfall pulses}

The response of sap flow to rainfall pulses is intimately correlated with the characteristics of the rainfall event (Stewart and Burgess, 2006); that is, the "pulse-reserve" paradigm for semiarid ecosystems suggests a strong linear relationship between pulses of rainfall and plant productivity (Reynolds et al., 2004). Generally, the plant's water-use strategies governed the rainfall 
threshold (Eberbach and Burrows, 2006). Time lags appear in the response of plant to rainfall pulses (Ogle and Reynolds, 2004). For example, Loik (2007) reported that Artemisia tridentata and Purshia tridentata in the Great Basin Desert responded within about 2 days to a range of summer rainfall pulse magnitudes, whereas the hemi-parasitic species Nuytsia floribunda (Loranthaceae) in southern Australia required more than 2 weeks to fully respond to rainfall events (Stewart and Burgess, 2006). Small events $(\leq 5 \mathrm{~mm})$ accounted for $48.6 \%$ of the events in the study region (Fig. 2). The lower rainfall thresholds of stem and branch were 5.2, $5.5 \mathrm{~mm}$ and $0.7,0.8 \mathrm{~mm}$ for $C$. korshinskii and $H$. rhamnoides, with lag times ranging from 4.21 to 5.16 days (Table 4), which also suggested that small rainfall events are critical for plant growth and survival.

The "pulse-reserve" paradigm suggested that the planted shrubs do not respond directly to rainfall, but rather respond to soil water availability (Reynolds et al., 2004). Small rainfall events can wet the plant surface, and plants can absorb rainwater adhering to their leaves and branches (through lenticels) and use the water to increase sap flow density. Large amounts of rainfall can effectively supply soil moisture and improve soil water availability (Reynolds et al., 2004), leading to a sap flow response in the stem after the rainfall. Also, our previous studies reported that 1-3 and 1-5 mm of rainfall being intercepted by the shrub canopy (mainly for leaves and branches) for $C$. korshinskii and $H$. rhamnoides (Jian et al., 2012). This explained why there were differences of rainfall threshold between stem and branches (Table 4). However, rainfall will significantly increase the relative humidity of air and decrease air temperature when rainfall is higher than the upper rainfall threshold, which will result in a decrease in sap flow.

The response of sap flow is related not only to the physiological characteristics, but also to environmental variables (Gao et al., 2011; Liu et al., 2012; Reyes-Acosta and Lubczynski, 2014). The sap flow response of these two shrubs to greater evaporative demand was shown to exhibit low $R^{2}$ values with increasing $Q_{\mathrm{o}}$ and $D_{z}$ (Fig. 6), indicating that $Q_{\mathrm{o}}$ and $D_{z}$ were not only influenced factors. Considering the low rainfall in June and September (Fig. 3E), soil water content was expected to be a key factor to determine sap flow in these two months. So it was concluded that the different drivers of sap flow existed in distinct period. Soil water content was more important than $Q_{0}$ and $D_{z}$ in influencing sap flow in June and September. When soil water content was sufficient, $Q_{\mathrm{o}}$ and $D_{z}$ were the dominant factors, but soil water content was the primary factor under low soil moisture levels. Gartner et al. (2009) found the same law in Norway spruce of European.

Our results also showed that sap flow in the stem in response to light was delayed more than sap flow in the branches in the morning, which might be explained by a slow stomatal response to light and to water conduction in the stem (O'Brien et al., 2004). The photo-inhibition that occurs in plants at noon (Liu and Zhao, 2008) would decrease the transpiration rate in the crown and sap flow density in the branches. However, the lag arises during the course of sap flow transmission from the roots to the crown (Ewers and Oren, 2000), which would not induce a "mid-afternoon depression" phenomenon for sap flow in the stem.

\section{Response of sap flow to water potential and $K_{\text {leaf }}$}

The water potential drops between leaves and stems and branches of after rainfall were higher than before rainfall (Fig. 7). This is consistent with previously reported results (Gallé et al., 2007; Sánchez-Blanco et al., 2002). The reason for the increment of water potential drops maybe that droughtinduced embolism is promptly refilled after rainfall (Sitková et al., 2014). In fact, the leaf provides probably the best environment for refilling of embolized conduits (Salleo et al., 2001) due to the relative abundance of inorganic ions and other osmolytes that could be used to generate positive pressures as well as possessing large amounts of metabolic energy to drive ion movement. In the current study, before rainfall, leaves in stems of $H$. rhamnoides lost nearly $100 \%$ of their $K_{\text {leaf }}$ but began to recover late in the day, while water potentials were still more negative than $-2.2 \mathrm{MPa}$ (Fig. 8A). Leaves in branches of $H$. rhamnoides and leaves in stems and branches of $C$. korshinskii also lost large percentages of $K_{\text {leaf }}$ but began to recover in the late afternoon while leaf water potentials were still highly negative before rainfall (Fig. 8B-D). After rainfall, there was a slight increase in $K_{\text {leaf }}$ in both $C$. korshinskii and H. rhamnoides between early morning and noon (Fig. 8E-H). Increases $K_{\text {leaf }}$ with increasing temperature and light have been previously reported for several species (Holbrook et al., 2001; O'Brien et al., 2004; Salleo et al., 2001; Voicu et al., 2008). The increase of $K_{\text {leaf }}$ was observed in previously water-stressed plants following rainfall. Good evidence exists to suggest that xylem tissue collapse (Brodribb and Holbrook, 2006; Salleo et al., 2001) and leaf turgor loss (Brodribb and Holbrook 2006, Gallé et al., 2007) may both play a part in the loss of $K_{\text {leaf }}$ in a variety of plants. Therefore, the rapid recovery of $K_{\text {leaf }}$ could also be attributed to the possible fact that the initial loss of $K_{\text {leaf }}$ is not associated with xylem cavitation. The shrubs may reflect the investment in those tissues and the need for a more conservative strategy as opposed to a less conservative strategy where (i) large losses of $K_{\text {leaf }}$ could lead to leaf death or (ii) large losses in $K_{\text {leaf }}$ must be repaired by what is likely an energetically expensive process, and rainfall pulses can maintain the balance (Brodribb and Holbrook, 2003; Voicu et al., 2008).

\section{CONCLUSIONS}

Small rainfall events can wet the plant surface to increase sap flow density in the branches. Soil moisture can be supplied effectively by large rainfall events. The response pattern followed the threshold-delay model, with lower rainfall thresholds of 5.2, $5.5 \mathrm{~mm}$ and $0.7,0.8 \mathrm{~mm}$ of stem and branch for $C$. korshinskii and $H$. rhamnoides, respectively. Therefore, small rainfall event had a positive effect on the survival and growth of shrubs in semi-arid regions. The greater frequency of smaller events may give them a greater impact than less-frequent larger rainfall events on plant physiological responses.

Acknowledgements. This project was supported by Startup Research Fund of Zhengzhou University (1512323001); Institution of higher learning key scientific research project, Henan Province (16A570010); National Natural Science Foundation of China (No. 51079131); China postdoctoral science foundation. All authors are grateful for the contribution from reviewers and editor Lubomir Lichner to this paper, including mails and comments to the manuscript.

\section{REFERENCES}

Amenu, G.G., Kumar, P., 2008. A model for hydraulic redistribution incorporating coupled soil-root moisture transport. Hydrol. Earth Syst. Sci., 12, 55-74.

BassiriRad, H., Tremmel, D.C., Virginia, R.A., Reynolds, J.F., de Soyza, A.G., Brunell, M.H., 1999. Short-term patterns in 
water and nitrogen acquisition by two desert shrubs following a simulated summer rain. Plant Ecol., 145, 27-36.

Blackman, C.J., Brodribb, T.J., 2011. Two measures of leaf capacitance: insights into the water transport pathway and hydraulic conductance in leaves. Funct. Plant Biol., 38, 118126.

Blackman, C.J., Brodribb, T.J., Jordan, G.J., 2010. Leaf hydraulic vulnerability is related to conduit dimensions and drought resistance across a diverse range of woody angiosperms. New Phytol., 188, 1113-1123.

Brodribb, T.J, Holbrook, N.M., 2003. Stomatal closure during leaf dehydration, correlation with other leaf physiological traits. Plant Physiol., 132, 2166-2173.

Brodribb, T.J., Holbrook, N.M., 2006. Declining hydraulic efficiency as transpiring leaves desiccate: two types of response. Plant Cell Environ., 29, 2205-2215.

Burgess, S.S.O., 2006. Measuring transpiration responses to summer precipitation in a Mediterranean climate: a simple screening tool for identifying plant water-use strategies. Physiol. Plant, 127, 404-412.

Cao, C.Y., Jiang, S.Y., Zhang, Y., Zhang, F.X., Han, X.S., 2011. Spatial variability of soil nutrients and microbiological properties after the establishment of leguminous shrub Caragana microphylla Lam. Plantation on sand dune in the Horqin Sandy Land of Northeast China. Ecol. Eng., 37, 1467-1475.

Chazdon, R.L., 2008. Beyond deforestation: restoring forests and ecosystem services on degraded lands. Science, 320, $1458-1460$.

Chen, L.D., Wang, J.P., Wei, W., Fu, B.J., Wu, D.P., 2010. Effects of landscape restoration on soil water storage and water use in the Loess Plateau Region, China. For. Ecol. Manage., 259, 1291-1298.

Cheng, X., An, S., Li, B., Chen, J., Lin, G., Liu, Y., Luo, Y., Liu, S., 2006. Summer rain pulse size and rainwater uptake by three dominant desert plants in a desertified grassland ecosystem in northwestern China. Plant Ecol., 184, 1-12.

Dawson, T.E., Burgess, S.S.O., Tu, K.P., Oliveira, R.S., Santiago, L.S., Fisher, J.B., Simonin, A.K., Ambrose, A.R., 2007. Nighttime transpiration in woody plants from contrasting ecosystems. Tree Physiol., 27, 561-575.

Domec, J.C., Scholz, F.G., Bucci, S.J., Meinzer, F.C., Goldstein, G., Villalobos-Vega, R., 2006. Diurnal and seasonal changes in root xylem embolism in neotropical savanna woody species: impact on stomatal control of plant water status. Plant Cell Environ., 29, 26-35.

Du, S., Wang, Y.L., Kume, T., Zhang, J.G., Otsuki, K., Yamanaka, N., Liu, G.B., 2011. Sapflow characteristics and climatic responses in three forest species in the semiarid Loess Plateau region of China. Agric. For. Meteorol., 151, 1-10.

Eberbach, P.L., Burrows, G.E., 2006. The transpiration response by four topographically distributed Eucalyptus species, to rainfall occurring during drought in south eastern Australia. Physiol. Plant, 127, 483-493.

Engel, V., Jobbagy, E.G., Stieglitz, M., Williams, M., Jackson, R.B., 2005. Hydrological consequences of eucalyptus afforestation in the Argentine pampas. Water Resour. Res., 41 (10), Art. No. W10409.

Ewers, B.E., Oren, R., 2000. Analysis of assumptions and errors in the calculation of stomatal conductance from sap flow measurements. Tree Physiol., 20, 579-589.

Falge, E., Baldocchi, D., Olson, R., Anthoni, P., Aubinet, M., Bernhofer, C., Burba, G., Ceulemans, R., Clement, R., Dolman, H., Granier, A., Gross, P., Grünwald, T., Hollinger, D., Jensen, N.O., Katul, G., Keronen, P., Kowalski, A., Lai,
C.T., Law, B.E., Meyers, T., Moncrieff, J., Moors, E., Munger, J.W., Pilegaard, K., Rannik, Ü., Reb-mann, C., Suyker, A., Tenhunen, J., Tu, K., Verma, S., Vesala, T., Wilson, K., Wofsy, S., 2001. Gap filling strategies for defensible annual sums of net ecosystem exchange. Agric. For. Meteorol., 107, 43-69.

Fravolini, A., Hultine, K.R., Brugnoli, E., Gazal, R., English, N.B., Williams, D.G., 2005. Precipitation pulse use by an invasive woody legume: the role of soil texture and pulse size. Oecologia, 144, 618-627.

Gallé, A., Haldimann, P., Feller, U., 2007. Photosynthetic performance and water relations in young pubescent oak (Quercus pubescens) trees during drought stress and recovery. New Phytol., 174, 799-810.

Gao, X., Wu, P., Zhao, X., Shi, Y., Wang, J., 2011. Estimating spatial mean soil water contents of sloping jujube orchards using temporal stability. Agric. Water Manage., 102, 66-73.

Gartner, K., Nadezhdina, N., Englisch, M., Cermak, J., Leitgeb, E., 2009. Sap flow of birch and Norway spruce during the European heat and drought in summer 2003. Forest Ecol. Manag., 258, 590-599.

Holbrook, N.M., Ahrens, E.T., Burns, M.J., Zwieniecki, M.A., 2001. In vivo observation of cavitation and embolism repair using magnetic resonance imaging. Plant Physiol., 126, 27-31.

IUSS Working Group WRB, 2006. World reference base for soil resources 2006. $2^{\text {nd }}$ edition. World Soil Resources Reports No. 203. FAO, Rome.

Ivans, S., Hipps, L., Leffler, A.J., Ivans, C.Y., 2006. Response of water vapor and $\mathrm{CO}_{2}$ fluxes in semiarid lands to seasonal and intermittent precipitation pulses. J. Hydrometeorol., 7, 995-1010.

Ježík, M., Blaženec, M., Letts, M.G., Ditmarová, L'., Sitková, Z., Střelcová, Z., 2015. Assessing seasonal drought stress response in Norway spruce (Picea abies (L.) Karst.) by monitoring stem circumference and sap flow. Ecohydrology, 8, 3, 378-386.

Jian, S.Q., Zhao, C.Y., Fang, S.M., Yu, K., 2014. Distribution of fine root biomass of main planting tree species in Loess Plateau, China. Chinese J. Appl. Ecol., 25, 1905-1911. (In Chinese with English summary.)

Jian, S.Q., Zhao, C.Y., Fang, S.M., Yu, K., Wang, Y., Liu, Y.Y., Zheng, X.L., Peng S.Z., 2012. Characteristics of rainfall interception by Caragana korshinskii and Hippophae rhamnoides in Loess Plateau of Northwest China. Chinese J. Appl. Ecol., 23, 2383-2389. (In Chinese with English summary.)

Jiao, F., Wen, Z.M., An, S.S., 2011. Changes in soil properties across a chronosequence of vegetation restoration on the Loess Plateau of China. Catena, 86, 110-116.

Kigalu, J.M., 2007. Effects of planting density on the productivity and water use of tea (Camellia sinensis L.) clones I. Measurement of water use in young tea using sap flow meters with a stem heat balance method. Agric. For. Meteorol., 90, 224-232.

Klein, T., Rotenberg, E., Cohen-Hilaleh, E., Raz-Yaseef, N., Tatarinov, F., Preisler, Y., Ogée, J., Cohen, S., Yakir, D., 2014. Quantifying transpirable soil water and its relations to tree water use dynamics in a water-limited pine forest. Ecohydrology, 7, 2, 409-419.

Kurz, C., Otieno, D., Lobo do Vale, R., Siegwolf, R., Schmidt, M., Herd, A., Nogueira, C., Soares David, T., Soares David, S., Tenhunen, J., Santos Pereira, J., Chaves, M., 2006. Hydraulic lift in cork oak trees in a savannah-type Mediterranean ecosystem and its contribution to the local water balance. Plant Soil, 282, 361-378. 
Liu, B., Zhao, W.Z., 2008. Characteristics and spatial heterogeneity of $T$. ramosissima nebkha at the desert-oasis ecotone. Acta Ecol. Sin., 28, 1446-1455.

Liu, C., Du, T., Li, F., Kang, S., Li, S., Tong, L., 2012. Trunk sap flow characteristics during two growth stages of apple tree and its relationships with affecting factors in an arid region of northwest China. Agric. Water Manage., 104, 193-202.

Loik, M., 2007. Sensitivity of water relations and photosynthesis to summer precipitation pulses for Artemisia tridentata and Purshia tridentata. Plant Ecol., 191, 95-108.

Ma, L.H., Wu, P.T., Wang, Y.K., 2012. Spatial distribution of roots in a dense jujube plantation in the semiarid hilly region of the Chinese Loess Plateau. Plant Soil, 2012, 45-61.

Moran, M.S., Scott, R.L., Keefer, T.O., Emmerich, W.E., Hernandez, M., Nearing, G.S., Paige, G.B., Cosh, M.H., O'Neill, P.E., 2009. Partitioning evapotranspiration in semiarid grassland and shrubland ecosystems using time series of soil surface temperature. Agric. For. Meteorol., 149, 59-72.

Morgan, H.D., Barton, C.V.M., 2008. Forest-scale sap flux responses to rainfall in a dryland eucalyptus plantation. Plant Soil, 305, 131-144.

Nadezhdina, N., Nadezhdin, V., Ferreira, M.I., Pitacco, A., 2007. Variability with xylem depth in sap flow in trunks and branches of mature olive trees. Tree Physiol., 27, 105-113.

Noy-Meir, I., 1973. Desert ecosystems: environment and producers. Annu. Rev. Ecol. Syst., 4, 25-52.

O'Brien, J.J., Oberbauer, S.F., Clark, D.B., 2004. Whole tree xylem sap flow responses to multiple environmental variables in a wet tropical forest. Plant Cell Environ., 27, 551567.

Ogle, K., Reynolds, J.F., 2004. Plant responses to precipitation in desert ecosystems: integrating functional types, pulses, thresholds, and delays. Oecologia, 141, 282-294.

Potts, D.L., Huxman, T.E., Cable, J.M., English, N.B., Ignace, D.D., Eilts, J.A., Mason, M.J., Weltzin, J.F., Williams, D.G., 2006. Antecedent moisture and seasonal precipitation influence the response of canopy-scale carbon and water exchange to rainfall pulses in a semi-arid grassland. New Phytol., 170, 849-860.

Rana, G., Katerji, N., de Lorenzi, F., 2005. Measurement and modelling of evapotranspiration of irrigated citrus orchard under Mediterranean conditions. Agric. For. Meteorol., 128, 199-209.

Reyes-Acosta, J.L., Lubczynski, M.W., 2014. Optimization of dry-season sap flow measurements in an oak semi-arid open woodland in Spain. Ecohydrology, 7, 2, 258-277.

Reynolds, J.F., Kemp, P.R., Ogle, K., Fernández, R.J., 2004. Modifying the 'pulse-reserve' paradigm for deserts of North America: precipitation pulses, soil water, and plant responses. Oecologia, 141, 194-210.

Salleo, S., Lo Gullo, M.A., Raimondo, F., Nardini, A., 2001. Vulnerability to cavitation of leaf minor veins: any impact on leaf gas exchange? Plant Cell Environ., 24, 851-859.

Sánchez-Blanco, M.J., Rodríguez, P., Morales, M.A., Ortuňo, M.F., Torrecillas, A., 2002. Comparative growth and water relations of Cistus albidus and Cistus monspeliensis plants during water deficit conditions and recovery. Plant Sci., 162, 107-113.

Schwinning, S., Starr, B.I., Ehleringer, J.R., 2003. Dominant cold desert plants do not partition warm season precipitation by event size. Oecologia, 136, 252-260.
Sitková, Z., Nalevanková, P., Střelcová, K., Fleischer, P., Ježík, M., Sitko, R., Pavlenda, P., Hlásny, T., 2014. How does soil water potential limit the seasonal dynamics of sap flow and circumference changes in European beech? Forest. J., 60, 1, 19-30.

Smith, D.M., Allen, S.J., 1996. Measurement of sap flow in plant stems. J. Exp. Bot., 47, 1833-1844.

Sperry, J.S., 1986. Relationship of xylem embolism to xylem pressure potential, stomatal closure, and shoot morphology in the palm Rhapis excelsa. Plant Physiol., 80, 110-116.

Sponseller, R.A., 2007. Precipitation pulses and soil $\mathrm{CO}_{2}$ flux in a Sonoran Desert ecosystem. Glob. Change Biol., 13, 426-436.

Stewart, S., Burgess, O., 2006. Measuring transpiration responses to summer precipitation in a Mediterranean climate: a simple screening tool for identifying plant water-use strategies. Physiol. Plant, 127, 404-412.

Voicu, M.C., Zwiazek, J.J., Tyree, M.T., 2008. Light response of hydraulic conductance in bur oak (Quercus macrocarpa) leaves. Tree Physiol., 28, 1007-1015.

Walter, H., 1971. Natural savannahs as a transition to the arid zone. In: Burnett, J.H. (Ed.): Ecology of Tropical and Subtropical Vegetation. Oliver and Boyd, Edinburgh, pp. 238265.

Wang, B., Zhang, G.H., Shi, Y.Y., Zhang, X.C., 2013. Effect of natural restoration time of abandoned farmland on soil detachment by overland flow in the Loess Plateau of China. Earth Surf. Proc. Land., 38, 1725-1734.

Wang, Y.Q., Shao, M.A., Shao, H.B., 2010. A preliminary investigation of the dynamic characteristics of dried soil layers on the Loess Plateau of China. J. Hydrol., 381, 9-17.

Wang, Y.Q., Shao, M.A., Zhu, Y.J., Liu, Z.P., 2011. Impacts of land use and plant characteristics on dried soil layers in different climatic regions on the Loess Plateau of China. Agric. For. Meteorol., 151, 437-448.

Wilson, K.B., Hanson, P.J., Mulholland, P.J., Baldocchi, D.D., Wullschleger, S.D., 2001. A comparison of methods for determining forest evapotranspiration and its components: sap flow, soil water budget, eddy covariance and catchment water balance. Agric. For. Meteorol., 106, 153-168.

Xiao, B., Wang, Q., Zhao, Y., Shao, M., 2011. Artificial culture of biological soil crusts and its effects on overland flow and infiltration under simulated rainfall. Appl. Soil Ecol. 48, 11-17.

Xu, H., Li, Y., 2006. Water-use strategy of three central Asian desert shrubs and their responses to rain pulse events. Plant Soil, 285, 5-17.

Yue, G., Zhao, G., Zhang, T., Zhao, X.Y., Niu, L., Drake, S., 2008. Evaluation of water use of Caragana microphylla with the stem heat-balance method in Horqin Sandy Land, Inner Mongolia, China. Agric. For. Meteorol., 148, 1668-1678.

Zeppel, M., Macinnis-Ng, C.M.O., Ford, C.R., Eamus, D., 2008. The response of sap flow to pulses of rain in a temperate Australian woodland. Plant Soil, 305, 121-130.

Zhang, G.H., Tang, M.K., Zhang, X.C., 2009. Temporal variation in soil detachment under different land uses in the Loess Plateau of China. Earth Surf. Proc. Land., 34, 1302-1309.

Received 9 December 2015 Accepted 12 April 2016 